\title{
How movies can ease the fear of death: the survival or death of the protagonists in meaningful movies
}

\author{
Rieger, Diana ; Hofer, Matthias
}

\begin{abstract}
Many media entertainment products address the fragility of life by portraying the severe illness or death of the protagonist. According to terror management theory, people need to create meaning in their lives when they are reminded of their own mortality, for instance, by engaging in close relationships with others. Meaningful films may provide recipients with an anxiety buffer that helps them to cope with existential fear. The results of an experimental study $(\mathrm{N}=130)$ demonstrated that participants who had been reminded of their mortality appreciated a meaningful movie more and liked the protagonist better when he survived than when he died. Further, participants who viewed the movie in which the protagonist survived did not activate their selfesteem-based anxiety buffer. The results point toward the potential of entertainment to provide internal anxiety buffers and thereby help in coping with self-threatening situations. The findings are discussed in terms of the connections between meaningful media entertainment, coping mechanisms, and viewers' terror management.
\end{abstract}

DOI: https://doi.org/10.1080/15205436.2017.1300666

Posted at the Zurich Open Repository and Archive, University of Zurich

ZORA URL: https://doi.org/10.5167/uzh-145364

Journal Article

Accepted Version

Originally published at:

Rieger, Diana; Hofer, Matthias (2017). How movies can ease the fear of death: the survival or death of the protagonists in meaningful movies. Mass Communication and Society, 20(5):710-733.

DOI: https://doi.org/10.1080/15205436.2017.1300666 


\title{
How Movies Can Ease the Fear of Death:
}

The Survival or Death of the Protagonists of Meaningful Movies

\begin{abstract}
Many media entertainment products address the fragility of life by portraying the severe illness or death of the protagonist. According to terror management theory, people need to create meaning in their lives when they are reminded of their own mortality, for instance by engaging in close relationships with others. Meaningful films may provide recipients with an anxiety buffer that helps them to cope with existential fear. The results of an experimental study $(N=130)$ demonstrated that participants who had been reminded of their mortality appreciated a meaningful movie more and liked the protagonist better when he survived than when he died. Further, participants who viewed the movie in which the protagonist survived did not activate their self-esteem-based anxiety buffer. The results point towards the potential of entertainment to provide internal anxiety buffers and thereby help in coping with self-threatening situations. The findings are discussed in terms of the connections between meaningful media entertainment, coping mechanisms and viewers' terror management.
\end{abstract}

Keywords: Mortality salience; appreciation; liking; self-esteem; meaningful films 
How Movies Can Ease the Fear of Death:

The Survival or Death of the Protagonists of Meaningful Movies

"I want something good to die for to make it beautiful to live" (Queens of the Stone Age).

Entertainment experiences have long been conceived as providing enjoyment, pleasure, fun, thrills, and relaxation (Bosshart \& Macconi, 1998). This hedonic enjoyment is regarded as being at the heart of the entertainment experience (Vorderer, Klimmt, \& Ritterfeld, 2004). However, this hedonic view is inconsistent with the fact that viewers also seem to be entertained by tragic movies that depict the heartbreaking fate or even the death of beloved characters (Feagin, 1983; Oliver, 1993). This observation has prompted entertainment scholars to extend the notion of entertainment to include so-called eudaimonic entertainment experiences (Oliver \& Bartsch, 2010; Oliver \& Hartmann, 2010; Wirth, Hofer, \& Schramm, 2012). According to this view, movies not only elicit pleasure or fun, but also negative or mixed emotions and so-called meaningful experiences (Oliver \& Hartmann, 2010; Oliver, 2008).

Entertainment media that are likely to promote eudaimonic entertainment experiences (socalled meaningful films) often depict fundamental questions of human existence and the meaning of life, showing viewers what makes life valuable and "beautiful to live". These questions are closely linked to the inevitability of death. Tsay, Krakowiak, and Oliver (2012) found that meaningful movies such as The Green Mile or Dancer in the Dark have the potential to remind viewers both of life's meaning and of the fact that every life must end someday. Human capacity to be aware of the fact that time is limited can cause a state of paralyzing terror that must be coped with (Simon, Arndt, Greenberg, Pyszczynski, \& Solomon, 1998). According to terror management theory (TMT; Greenberg, Solomon, \& Pyszczynski, 1997; Simon et al., 1997), people cope with the existential fear of death through the creation and pursuit of meaning. This 
can be accomplished through adherence to cultural worldviews, enhancement of one's selfesteem, or engagement in or maintenance of close relationships (Greenberg et al., 1992; Mikulincer, Florian, \& Hirschberger, 2003). In the context of communication research, meaningful films can help recipients to cope with the fear of death, because these films can serve as an inspiration for generating meaning.

Accordingly, Hofer (2013) found that participants who were reminded of their mortality appreciated a meaningful film in which the protagonist died at the end more than did those who were not given such a reminder. Another recent study demonstrated that, after the threat of death was made salient, a meaningful film was more able to buffer anxious responses than was a pleasurable or informative film (AUTHORS).

However, although these studies have shown that meaningful films can help recipients to cope with the fear of death, the crucial content elements and response mechanisms are still unknown. Goldenberg, Pyszczynski, Johnson, Greenberg, and Solomon (1999) have argued that the vicarious experience of the death of a protagonist can help recipients to cope with the terror associated with existential fears. Other researchers have suggested that inducing meaning through life-related thoughts such as hope (Wisman \& Heflick, 2015) can serve as an antidote against the paralyzing terror caused by mortality salience. According to this idea, a meaningful film only serves as an anxiety buffer if the protagonist remains alive at the end of the film.

To clarify this key point, the present study set out to examine whether the survival or death of the protagonist in a meaningful film can serve as a buffer against the fear of death induced by mortality salience. Reminders of one's own mortality generate an urge to find meaning, which can be provided by a meaningful film. The depiction of a protagonist who survives a challenging life-threatening situation, a common topic in meaningful films (e.g., a character confronted with severe illness), may offer a buffer to the audience by symbolically 
overcoming the inevitability of death. Alternatively, and in line with the arguments posited by the originators of TMT, depictions of death (such as a protagonist who dies in a challenging lifethreatening situation) might also be perceived as beneficial, because the fictional frame provides a safe environment for such issues without involving real consequences (Goldenberg, Pyszczynski, Johnson, Greenberg, \& Solomon, 1999).

Hence, the present work makes an important contribution to understanding meaningful entertainment in the context of TMT in two central ways: (1) It extends previous research by investigating a specific aspect of meaningful films, namely, how portraying the survival or death of the protagonist affects viewers' entertainment experiences following a mortality salience induction; and (2) it addresses the question of whether the depiction of life or death through meaningful entertainment can serve as an anxiety buffer, as described within the framework of TMT.

\section{Meaning and Terror Management Theory}

All humans strive for coherence in what they are doing and seek to ascribe personal meaning to their actions. This central psychological tenet was promoted by both Sigmund Freud and Alfred W. Adler, who claimed that "human beings live in the realm of meanings" (Adler, 1980, p. 1). This idea is also echoed by Baumeister and Vohs (2002), who showed meaning to be a central condition for happiness. Although there are individual differences in people's need for meaning and coherence, all humans seek to reduce complexity by adhering as coherently as possible to their own self-view (Swann \& Brooks, 2012). It is not surprising, therefore, that researchers have concluded that people have a need for meaning in their lives (Heine, Proulx, \& Vohs, 2006; Steger, Kashdan, Sullivan, \& Lorentz, 2008; Steger, Kawabata, Shimai, \& Otake, 2008; Steger, Oishi, \& Kesebir, 2011). This basic need becomes even more pronounced when 
individuals are forced to reflect on the inevitability of death, such as after near-death encounters (e.g., Zamora, 2006).

TMT is based on the assumption that every human being is caught in a dilemma between the instinct for self-preservation and the cognitive realization that he or she has to die someday (Greenberg et al., 1995). The main coping mechanism for managing this dilemma is to create a buffer against the frightening awareness of the inevitability of death. According to TMT, a reminder of death generates an urge to find meaning through symbolic immortality (Arndt \& Vess, 2008; Mikulincer et al., 2003; Vess, Routledge, Landau, \& Arndt, 2009). To handle the threat of death, humans engage in both conscious (proximal) and subconscious (distal) coping mechanisms, called anxiety buffers (Pyszczynski, Greenberg, \& Solomon, 1999). Proximal anxiety buffers are used when individuals are consciously aware of their mortality. They address the threat of death directly and consciously by increasing the intention to engage in lifeprolonging behavior - for instance eating healthy food or using sun protection (Routledge, Arndt, \& Goldenberg, 2004) - or by pushing the problem of death into the distant future (Pyszczynski et al., 1999). Distal anxiety buffers are used when thoughts of one's own death are no longer conscious, but are still accessible. Distal anxiety buffers are manifested in a symbolic anxiety buffer, which promises symbolic immortality via one's cultural worldview, self-esteem (Greenberg, Pyszczynski, \& Solomon, 1986), or close relationships (Mikulincer, Florian, Birnbaum, \& Malishkevich, 2002).

Two main hypotheses can be derived from this interplay between death and defense. The first, the mortality salience hypothesis, predicts that, when mortality is salient, individuals will activate proximal or distal anxiety buffers to cope with death-related thoughts. For instance, they might validate their cultural worldview by preferring people who confirm it and feeling disdain for those who threaten it. Relatedly, individuals under conditions of mortality salience have been 
found to judge those who share their religious views (Greenberg et al., 1990; Kosloff, Greenberg, Sullivan, \& Weise, 2010) or political values (Burke, Kosloff, \& Landau, 2013) as more appealing than those who do not share these views. Mortality salience also promotes a drive to increase one's self-esteem (Pyszczynski, Greenberg, Solomon, Arndt, \& Schimel, 2004), thereby promoting self-esteem-relevant behavior and self-serving biases (Goldenberg, Arndt, Hart, \& Brown, 2005; Routledge et al., 2004).

A third distal anxiety buffer consists of the motivation to form and maintain close relationships. In other words, it is suggested that humans have an innate attachment system that motivates them to retain proximity to close others, and that becomes more pronounced in the presence of death-related thoughts (Mikulincer \& Florian, 2000). In the context of meaningful entertainment, when mortality is made salient, viewers will prefer characters who defend their cultural worldview and entertainment that validates their self-esteem or features close relationships.

The second main hypothesis is the anxiety buffer hypothesis, which posits that, if a buffer is present, no additional buffer is necessary. In other words, if one's cultural worldview, selfesteem, or close relationships are sufficient to shield against the threat of death, there is less need to engage in additional defenses when mortality salience increases (Greenberg, Pyszczynski, Solomon, Simon, \& Breus, 1994). For example, Harmon-Jones et al. (1997) showed that people with high self-esteem had less need to defend their worldviews after mortality was made salient. In the context of meaningful entertainment, a viewer who builds a (close) relationship with the characters will have no need to activate the cultural worldview or self-esteem component for the coping mechanism to be successful.

With regard to communication research, recent conceptualizations suggest that entertainment media not only serve pleasure-seeking motivations, but also more profound 
meaning-seeking purposes (Oliver \& Bartsch, 2010, 2011; Oliver \& Raney, 2011). The following sections outline how meaningful media might operate as a possible buffer against anxiety about death.

\section{Meaning in Meaningful Media}

Entertainment research has seen a shift from a primarily hedonic view to a so-called eudaimonic view (Oliver \& Bartsch, 2010; Wirth et al., 2012). Ultimately, meaningful entertainment provides insight into the greater questions of the meaning of life; meaningful films have been found, for example, to activate central life values (Hofer, Allemand, \& Martin, 2014; Wirth, et al., 2012), elicit experiences of mastery (Rieger, Reinecke, Frischlich, \& Bente, 2014), inspire recipients to create meaning themselves (Oliver \& Bartsch, 2010, 2011; Oliver \& Hartmann, 2010), and stimulate feelings of elevation (Oliver, Hartmann, \& Woolley, 2012). Meaningful movies may therefore help people to cope with their own mortality by reminding viewers of the deeper meaning of life, or of the values and virtues that will persist even after their death (Hofer, 2013; Klimmt, 2011). In their book on death in classic and contemporary film, Sullivan and colleagues discussed several ways in which films cover the subject of death while also finding ways to help viewers cope with the topic (Sullivan \& Greenberg, 2013). For instance, they interpreted the message of Life is Beautiful as follows: "The message fits TMT perfectly: that life is beautiful only if we contrive through our worldviews to make it so. It is otherwise an intolerable nightmare that ends only in obliteration for self and all whom you love. In this sense, the film pulls no punches about the need for human imagination to create illusions to make life palatable and even beautiful. The film promotes the value of such illusory worldviews and the role of love in our perpetuation of them" (p. 26). This view suggests that a meaningful film provides a perspective that can help, as Klimmt (2011) put it, to "work through" a threat such as one's own mortality. Meaningful films, in general, might help viewers to do this 
because they provide viewers with the opportunity to attach themselves to a larger, more meaningful framework (see Kneer et al., 2011).

To date, only a few experimental studies have addressed how mortality salience influences media choices and the effects of those choices. Using novels, Goldenberg et al. (1999) demonstrated that tragedies can help people to cope with death-related thoughts by providing a safe fictional confrontation with life's finitude. Taylor (2013) found that, when confronted with death-related thoughts, people preferred television content that featured intimate relationships, confirming the anxiety-buffering power of close relationships. Similarly, people showed a greater desire to date people who were similar to those from their own in-group (Frischlich, Rieger, Dratsch, \& Bente, 2014) and identified more with a virtual team composed of people similar to themselves in a video game after being reminded of their own mortality (Frischlich, Rieger, \& Rutkowski, 2014). In all of these instances, engaging in meaningful interactions or relationships - even with mediated characters or avatars - may have served as an anxiety buffer.

The first study to relate terror management directly to different entertainment experiences, and to appreciation in particular, was conducted by Hofer (2013). He examined the effects of mortality salience on the perception of meaningful movies by including the search for meaning in life as a potential moderator. The results of the study showed that, when mortality was made salient, participants who scored highly on the search for meaning in life appreciated the meaningful movie more than did those in the control condition. Building on these results, a recent study demonstrated that people not only appreciated a meaningful movie more than other movie stimuli when confronted with death-related thoughts, but also that they no longer exhibited the defense mechanisms proposed by TMT. That is, after watching a meaningful movie excerpt (compared with a pleasurable or informative excerpt), participants no longer showed an increase in self-esteem activation (AUTHORS). Thus, if anxiety-buffering structures were already 
contained within the media stimulus, a second buffer (in this case, self-esteem defense) was no longer necessary.

In conclusion, research to date has demonstrated that meaningful movies provide viewers with something that serves as an anxiety buffer against death-related thoughts. However, this research has not answered the question of which aspects of meaningful films contribute to their apparent anxiety-buffering function. To further complicate the issue, Tsay, Krakowiak, and Oliver (2012) found that meaningful films themselves can remind viewers of their mortality. Participants in a longitudinal study who watched Six Feet Under (an HBO series about a family that runs a funeral home) reported a heightened fear of death and death avoidance (Schiappa, Gregg, \& Hewes, 2004). Moreover, reminders of mortality in a story about the death of a child were found to induce mortality salience in participants (Norenzayan \& Hansen, 2006). Taking these results into account, it seems that it is not meaningful films per se that provide a coping mechanism against death-related thoughts, but rather specific elements within the meaningful offering. Thus, for a meaningful film to act as an anxiety buffer, it might be crucial to emphasize life instead of death.

The current study operationalized the distinction between features of life versus death in a meaningful film by providing information about the survival or death of the main character. One could argue that it is not the death of a protagonist, but his or her survival-a depiction of life's strength — that serves as the anxiety buffer. Fictional encounters with death could still provide room for ideas about how to overcome death and provide solace through the hope of a continuing life or a postponed death (Klimmt, 2011). Accordingly, Wisman and Heflick (2015) found that upholding literal immortality beliefs helped people to cope with the loss of hope in response to a mortality salience threat. The authors concluded that hope is an example of a mechanism that can help people to adjust psychologically when thinking about their own death. 
These thoughts are in line with the temporarily expanding the boundaries of the self (TEBOTS) model (Slater, Johnson, Cohen, Comello, \& Ewoldsen, 2014). This model suggests that stories help their recipients to overcome the limited boundaries of the self and provide them with room to expand. According to the authors, this function becomes more important in certain life episodes or situations. Slater et al. (2014), among others, hypothesized that people are more likely to seek stories at times when their sense of self is threatened. In two recent studies, they found that fictional stories led to greater appreciation when the self was threatened by self-control depletion (Johnson, Ewoldsen, \& Slater, 2015) and by a need for self-affirmation (Johnson, Slater, Silver, \& Ewoldsen, 2016). Applying these findings to mortality salience as a severe threat to the self (Jonas et al., 2014), we hypothesized that mortality salience would lead to greater appreciation of a meaningful film (H1). In particular, we predicted that participants in the mortality-threatened condition would appreciate a movie in which the protagonist survived more than would participants in the other conditions (a priori contrast, $\mathrm{H} 2$ ).

Similar to the assumptions made for appreciation, the TEBOTS model also predicts that threats to the self increase the identification with the protagonist (Slater et al., 2014). In fact, the viewer's relationship with the protagonist (e.g., whether he or she identifies with, likes, and cares for him or her) is strongly associated with appreciation of the movie; however, whereas liking has a specific target, namely the protagonist of the movie, appreciation is related to the movie as a whole or to a specific scene. The whole movie, of course, also includes the protagonist. In line with research on the importance of close relationships and identification in threatening situations such as when thinking about mortality (Frischlich et al., 2014; Mikulincer et al., 2002), mortality salience should increase viewers' positive attitudes toward the protagonist. Previous research has considered these ideas by examining issues of similarity; for instance, when people are reminded of their mortality, they like others better if they share their ethnic background, their cultural 
worldview, and their values (see, e.g., Frischlich, Rieger, Dratsch, \& Bente, 2015; Kosloff et al., 2010). We therefore hypothesized that those in the mortality salience condition would like and care about the protagonist more than would those in the control condition (H3).

However, the film's ending should also influence how much the viewer likes the protagonist. It is well established that a protagonist who is liked is more likely to be positively evaluated by viewers (Raney, 2003). Therefore, the effect of mortality salience on viewers' liking of and caring for a protagonist should be especially pronounced when the protagonist does not die at the end of the film. For instance, social identity research (Tajfel \& Turner, 1979) has shown that a social group to which an individual feels a sense of belonging loses its self-esteem-relevant function for that individual if it is portrayed as undesirable (Arndt, Greenberg, Schimel, Pyszczynski, \& Solomon, 2002) or unsuccessful (Dechesne, Greenberg, Arndt, \& Schimel, 2000). Accordingly, when a protagonist dies, it reminds viewers of their own mortality, and thus the protagonist might lose his or her capacity to buffer viewers' death anxieties, possibly even turning into a self-relevant threat for recipients whose mortality has not been made salient. Building on our third hypothesis, we expected that mortality-threatened participants who viewed the survival of the protagonist would like and care for the protagonist more than would participants in the other conditions (a priori contrast, H4).

Finally, given the finding that the presence of one anxiety buffer decreases the need for an additional buffer (Greenberg et al., 1994), we expanded this logic to the issue of meaningful entertainment. In a previous study, we found that meaningful films provided viewers with a coping mechanism against death-related thoughts so that, after the reception of meaningful film stimulus, no additional anxiety buffer was applied (AUTHORS). The current study tested the assumption that it is aspects of life rather than death that are crucial for meaningful entertainment to be considered as helpful for mortality-threatened individuals. We predicted that viewers would 
(have to) defend these positive aspects of themselves as anxiety buffer only if the protagonist died at the end of the film — not if he survived. We thus hypothesized that implicit self-esteem activation would be lower in the mortality-threatened condition, but only for those who watched the film in which the protagonist survived (a priori contrast, H5).

\section{Method}

\section{A Priori Power Analysis}

The a priori effect size was calculated using data obtained from a meta-analysis of mortality salience effects (Burke et al., 2010) and similar research in media psychology (AUTHORS; Hofer, 2013). Whereas the average effect size in classic mortality salience experiments was calculated as $r=.34$, the effect sizes in studies that examined the effect of mortality salience on entertainment evaluations ranged from small ( $r=.13$, AUTHORS) to medium ( $r=.27$, Hofer, 2013). Taking these three references together, we estimated that the average effect size would be medium $(r=.25)$. A power analysis performed with $\mathrm{G}^{*}$ Power indicated that 128 participants would provide adequate power (.80) in a between-subjects analysis of variance (ANOVA).

\section{Participants}

In total, 130 undergraduate students participated in the experiment, of whom $30.8 \%$ ( $n=$ 40) were male and $69.2 \%(n=90)$ were female. The average age was 25.33 years $(S D=7.00)$. The experiment took place at a large university in Germany.

\section{Design and Stimulus Materials}

The study used a 2 (mortality salience vs. control) $\times 2$ (film ending: protagonist dies vs. protagonist survives) between-subjects design. A shortened version of the 2008 Canadian film One Week (directed by Michael McGowan) was used as the stimulus. The film features Ben, a young Canadian elementary school teacher who has been diagnosed with an aggressive form of 
cancer in its final stage. Although he requires immediate treatment, Ben instead decides to take a motorcycle trip across Canada. During the trip, he reflects on the meaning of his own life and life in general, and reconsiders getting married to his long-time girlfriend. In the final sequence of the film, the narrator reads aloud a passage from a book written by Ben, called One Week, an ending that makes it unclear whether Ben dies or survives.

\section{Experimental Manipulation}

The film ending was manipulated as follows: After the open ending, participants were either informed that Ben underwent cancer treatment and survived $(n=65)$, or that Ben died a few days later $(n=65)$. These different endings were communicated via information on screen at the end of the film, presented in a cinematic manner. Both versions of the shortened film were 31 minutes and 52 seconds long.

Mortality salience was manipulated using techniques developed in previous studies (Goldenberg et al., 1999; Greenberg, Simon, Pyszczynski, Solomon, \& Chatel, 1992). One group of participants $(n=63)$ was asked to write about their feelings when thinking about their own death and what they thought would happen to them, both as they died and after they were dead. The participants in the other group $(n=67)$ were asked to write about their thoughts and feelings about watching television. The participants were randomly assigned to one of the four experimental groups (low vs. high mortality salience x protagonist death vs. survival).

\section{Procedure}

The participants arrived at the laboratory alone or in groups of two or four. They were welcomed and seated in individual cubicles with computer screens and were asked to read and sign an informed consent form before starting the study. First, they filled out a personality questionnaire and completed a baseline measure of implicit self-esteem (see the Measures section below). The participants were then randomly assigned either to the mortality salience induction 
(death essay) or to the control group (TV essay). This procedure took about five minutes. Next, they watched the movie with either the happy ending (in which the protagonist survived) or the sad ending (in which the protagonist died). After watching the film, the participants filled out the questionnaire with the dependent measures, including the second implicit self-esteem measure.

Finally, the participants were debriefed and dismissed.

\section{Measures}

Appreciation. Appreciation was assessed with the moving/thought-provoking and the lastingimpression scales constructed by Oliver and Bartsch (2010). One example item is, "I found this movie to be very meaningful." Participants responded on a 7-point Likert scale ranging from 1 ("I strongly disagree") to 7 ("I strongly agree"). Before collapsing the items into one index, they were submitted to an exploratory factor analysis with promax rotation $(\kappa=4)$. The analysis clearly indicated a one-factor solution that accounted for $77.97 \%$ of the variance (eigenvalue $=$ 4.67, factor loadings: .74-.95). The resulting index had excellent reliability $(\alpha=.94, M=4.73$, $S D=1.45)$

Liking or caring for the character. Liking or caring for the character of Ben was measured by six items (e.g., "How much do you like Ben?" and "How much did you care for Ben?”). Participants responded on a 5-point Likert scale ranging from 1 ("not at all") to 5 ("very much") $(\alpha=.91, M=4.01, S D=0.81)$.

Self-esteem. As previous research has demonstrated a higher implicit defense of self-esteemrelated concepts after mortality salience induction (Kosloff et al., 2010), we used a responselatency-based implicit measure to examine self-esteem defense. This follows the approach taken in our previous mortality salience studies (AUTHORS). Drawing upon self-evaluation research (Mussweiler \& Bodenhausen, 2002), the participants were asked to evaluate the extent to which 20 positive (e.g., "intelligent") and 20 negative (e.g., "cruel”) traits applied to them. The 
adjectives were randomly ordered, and participants responded on a 9-point Likert scale ranging from 1 ("not at all") to 9 ("totally") $\left(\alpha_{\mathrm{t} 1 \text { pos }}=.93, M=7.22, S D=0.86 ; \alpha_{\mathrm{t} 1 \text { neg }}=.88, M=2.68, S D\right.$ $\left.=0.96 ; \alpha_{\mathrm{t} 2 \mathrm{pos}}=.89, M=7.24, S D=0.90 ; \alpha_{\mathrm{t} 2 \mathrm{neg}}=.88, M=2.45, S D=0.93\right)$.

Self-esteem defense was measured via response latencies, with shorter latencies indicating higher implicit accessibility of self-esteem components. To control for preexisting differences in self-esteem activation (Schmeichel et al., 2009), the adjectives were presented twice: The first measurement served as a baseline, and the second measurement was taken after the participants had watched the shortened version of the film. A combined score for positive and negative adjectives was created by subtracting the response latencies for negative adjectives from those for positive adjectives $\left(\mathrm{rt}_{\text {pos }}-\mathrm{rt}_{\mathrm{neg}}\right)$. This procedure was chosen because shorter response latencies in response to positive adjectives indicate higher accessibility of positive traits and thus higher selfesteem, whereas shorter response latencies in response to negative adjectives indicate higher accessibility of negative traits and hence lower self-esteem. The combined score thus serves as an indicator of the accessibility of positive over negative adjectives, with a score close to 0 indicating equal accessibility of negative and positive traits. Positive values indicate higher accessibility of negative traits and thus lower self-esteem, whereas negative values indicate higher accessibility of positive traits and thus higher self-esteem. Referring to H5, we expected participants to defend their implicit self-esteem and to respond faster to positive adjectives when mortality was salient in all conditions, except when the protagonist survived.

\section{Results}

To test the hypotheses, univariate ANOVAs and planned Helmert contrast analyses were conducted for each dependent variable based on previous studies (AUTHORS). The means, standard deviations (or standard errors in the case of self-esteem), and simple pairwise comparisons for all dependent variables are given in Table 1. 
[Insert Table 1 about here]

\section{Appreciation and Liking/Caring}

H1 predicted that participants who had been induced to confront their own death would have greater appreciation for a meaningful movie, and $\mathrm{H} 2$ predicted that this effect would be especially pronounced when the protagonist of the movie survived. Accordingly, $\mathrm{H} 3$ and $\mathrm{H} 4$ specified the same assumptions for liking and caring for the protagonist.

To account for the associations between appreciation and liking/caring, we conducted a MANOVA with mortality salience and the survival/death of the protagonist as the two dichotomous between-subject factors. The analysis revealed a significant multivariate effect of mortality salience (Wilk's $\lambda=.93$, multivariate $F(2,125)=4.94, p=.009, \eta_{\mathrm{p}}{ }^{2}=.07$ ). The multivariate main effect of the survival/death of the protagonist (Wilk's $\lambda=.97$, multivariate $F(2$, $125)=1.74, p=.179$, ) and the interaction (Wilk's $\lambda=.99$, multivariate $F(2,125)=0.97, p=$ .382) were not significant.

Separate univariate ANOVAs were calculated to test the individual effects on the outcome variables. This analysis revealed a significant main effect of mortality salience on appreciation $\left(F(1,126)=9.95, p=.002, \eta_{\mathrm{p}}{ }^{2}=.07\right)$. The main effect of the protagonist's survival did not reach significance $(F(1,126)=2.79, p=.097)$, nor did the interaction $(F(1,126)=1.54, p=$ .216). H1 was thus supported by the data.

We used contrast weights to formalize the assumption of $\mathrm{H} 2$ that only the movie featuring the protagonist's survival would increase appreciation in participants confronted with their own death. Appreciation was expected to be higher in the mortality salience $\times$ protagonist survives condition (contrast weight $=3$ ) than in all other conditions (contrast weight $=-1$ ). The contrast analysis confirmed that participants who were reminded of their mortality and then watched the meaningful film in which the protagonist survived appreciated the film more than did the 
participants in all other conditions $(t(92.16)=4.55, p<.001)$. The results of this contrast analysis therefore supported $\mathrm{H} 2$.

The main effect of mortality salience revealed significant differences for liking and caring for the protagonist $\left(F(1,126)=6.69, p=.011, \eta_{\mathrm{p}}{ }^{2}=.05\right)$. Participants in the mortality-threatened condition reported that they liked and cared for the protagonist more than did participants in the control condition. H3 was thus supported by the data. In contrast, no main effect was found for the survival/death of the protagonist $(F(1,126)=3.46, p=.065)$, and there was also no significant interaction effect $(F(1,126)=1.93, p=.168)$.

An additional contrast analysis using the same contrast weights as in the analysis for appreciation was significant $(t(98.52)=4.50, p<.001)$, indicating that participants liked and cared for the protagonist significantly more when he survived and when the participants had been reminded of their mortality beforehand (see Figure 2). Thus, H4 was supported.

[Insert Figure 2 about here]

\section{Self-esteem}

To account for individual differences in self-esteem activation, the difference score for baseline self-esteem activation served as the covariate in the analysis of self-esteem (ANCOVA). The analysis revealed that there was no main effect for either mortality salience $(F(1,125)=$ $3.11, p=.08)$ or the survival/death of the protagonist $(F(1,125)=0.91, p=.342)$. However, there was a significant interaction effect $\left(F(1,125)=4.75, p=.031, \eta_{\mathrm{p}}{ }^{2}=.04\right)$. The effect of the covariate was not significant $(F(1,125)=1.43, p=.23)$. As can be seen in Figure 3, participants who were reminded of their mortality and then watched the movie in which the protagonist survived had slower reaction times than did participants in the other conditions. The same contrast analysis as for $\mathrm{H} 2$ and $\mathrm{H} 4$ was applied here. A significant contrast was detected $(t(126)=$ 
$2.58, p=.011)$. As self-esteem defense was significantly lower when the protagonist survived and the participant's mortality was made salient beforehand, H5 was supported.

[Insert Figure 3 here]

\section{Discussion}

In the present study, we examined the anxiety-buffering function of a meaningful film. In accordance with previous research (AUTHORS; Hofer, 2013), we argued that watching meaningful films can help viewers to cope with the knowledge of the inevitability of their own death and with the anxiety associated with this knowledge. As a result, we predicted that, in the version of the film in which the strength of life was salient at the end-where the protagonist overcame cancer and survived — the film itself would serve as an anxiety buffer against the existential fear triggered by the mortality salience induction before the film. Our analyses showed that this was indeed the case. Meaningful movies thus seem to provide audiences with a means of coping with the idea of mortality, particularly when the movie combines reflection on the meaning of life with a message about the strength of life (i.e., the survival of the protagonist after a life-threatening journey; c.f., Klimmt, 2011).

The second proposed mechanism was that meaningful movies serve as an anxiety buffer in the form of close and meaningful interactions or even relationships with the mediated characters on screen. Therefore, we predicted the same pattern with regard to liking and caring for the main character, Ben, in $\mathrm{H} 3$ and in $\mathrm{H} 4$, respectively. Our results provided support for both H3 and H4. Participants who had been reminded of their mortality liked and cared for the protagonist more than did those who had not been reminded of their mortality before viewing the film (H3). Moreover, participants who were reminded of their mortality before viewing and then viewed a film offering hope for continuing life (i.e., the protagonist survived) reported the highest levels of liking and caring for the protagonist. 
Reflecting on these findings, we can conclude that a film that makes life's strength salient by implying that a protagonist can survive a severe illness can help people to cope with the paralyzing terror caused by reminders of their own mortality. We should mention, however, that the effects were strongest for the mortality salience conditions (as indicated by the main effects for mortality salience, H1 and H3). A meaningful film leads to heightened appreciation when participants feel threatened. This is in line with the theoretical assumptions of Slater et al. (2014), according to which stories are more appealing when the individual is in a threatening situation. Further, the univariate analyses showed a tendency for the survival of the protagonist to lead to higher appreciation and liking and caring for the protagonist $(p \mathrm{~s}<.10)$. Although these trends did not reach statistical significance, they shed some light on the experience-enhancing effect of entertainment that emphasizes the strength of life.

Finally, we hypothesized that, once a film has exerted its anxiety-buffering potential, other anxiety buffers become less relevant or even obsolete; we measured implicit self-esteem to assess the operation of this anxiety buffer outside of the movie. As predicted by H5, self-esteem defense was lowest (as evidenced by the slowest response times) among participants who both were reminded of their own mortality and saw the film version depicting the protagonist's survival. This supports our argument that when a film provides a means of buffering against the paralyzing fear of death, other subsequent anxiety buffers such as self-esteem become obsolete (AUTHORS).

Altogether, the results of the present study show that a display of life's strength can inoculate individuals against the anxiety elicited by a reminder of death. One supposed coping mechanism that helps to defend against mortality salience is also related to the perception that life is short and therefore a 'precious' good (see King et al., 2009). The fact that the protagonist 
survives a challenging life situation can help to postpone thoughts of death to the distant future or imbue life with meaning by giving hope.

This idea also implies that when a narrative makes death salient but does not offer a source of meaning, the viewer switches to other sources of meaning (Heine, Proulx, \& Vohs, 2006). These sources typically include the anxiety buffers described by TMT: an individual's self-esteem, cultural worldview, and close relationships (Arndt \& Vess, 2008; Mikulincer, Florian, \& Hirschberger, 2003; Vess, Routledge, Landau, \& Arndt, 2009). Our results revealed that the participants liked and cared for the protagonist most when they had been reminded of their mortality and when the protagonist survived a challenging situation. This finding highlights the importance of close relationships and proximity to others, even in fictional encounters.

However, liking a protagonist and appreciating the movie are related constructs (see, e.g., Johnson et al., 2015, 2016). The results therefore support the idea that meaningful films shape our response to death-related thoughts, but only when they contain elements of life, hope, positivity, and optimism. This study therefore clarifies that it is not meaningful films per se that help people to deal with death-related thoughts, but only those films that emphasize life instead of death. Meaningful films can satisfy a heightened need for meaningfulness (Greenberg, Solomon, \& Pyszczynski, 1997) or close relationships (Mikulincer et al., 2003) by emphasizing that life can beat death, at least some of the time.

However, the study does not explain the mechanisms (mediators or moderators) that lead to this anxiety-buffering function. Entertainment in general (not just meaningful films) can provide many triggers for the cognitive and affective mechanisms known to serve anxietybuffering functions. First, many entertainment offerings are enjoyable and pleasurable to watch (Vorderer et al., 2004), and positive affect may contribute to the mechanisms that serve as anxiety buffers (e.g., DeWall \& Baumeister, 2007). Second, films can provide hope and solace 
(Klimmt, 2011), justice (Taylor, 2012), and they can portray similar people and cultural worldviews (Hoffner \& Buchanan, 2005), moral values and virtues (Oliver et al., 2012), and close (mediated) relationships (Hartmann \& Goldhoorn, 2011). Mechanisms such as transportation and identification that are triggered by entertainment can further lead to changes in one's self-concept (Sestir \& Green, 2010). Future research is therefore needed to disentangle the mechanisms at play and to derive the important mediators that make coping mechanisms an effective response to entertainment messages.

\section{Limitations and Directions for Future Research}

Some limitations of the present study must be acknowledged. First, some of the nonsignificant or only marginally significant effects may have been because of the sample size of the present study. Although the a priori power analysis suggested that a sample size of 130 was sufficient to detect the expected medium-sized effects, other studies on mortality salience and entertainment have only found small effects (AUTHORS). Thus, rather than ignore the nonsignificant findings in this study, future studies should instead contextualize them to help shed light on the different processes that operate when people consume entertainment as a response to mortality salience. For instance, it is possible that the movie used in the present study weakened the effect of the mortality salience induction. At the very beginning of the film, there is a subtle reminder of death when Ben is given his diagnosis and his thoughts of shooting himself are visualized for the viewer. Further, in one of the film's endings, the viewer is told that Ben died. Previous studies on mortality salience and media content have used stimulus materials both with (Hofer, 2013; Kneer \& Rieger, 2016) and without (AUTHORS, Taylor, 2012, 2013) death reminders and have produced similar effects. However, to date, no study has tested whether additional death reminders within the potential coping material alter viewers' responses in a self- 
threatening situation. It could be argued that viewers distinguish between thinking about their own death and fictional portrayals of death (see Goldenberg et al., 1999, for a discussion).

Second, as our experiment only used one movie, we cannot rule out the possibility that our results are based on the specific characteristics of the stimulus message. Although the stimulus selection supported the internal validity of our design, future studies should use a broader variety of film stimuli featuring different aspects of meaningfulness, such as law and order, hope, or moral virtue. This would provide evidence for the generalizability of the results and would help to increase the understanding of the mechanisms of anxiety buffers in meaningful films.

Third, audience age is likely to play an important role in the present context. Recent research has demonstrated that older viewers appreciate meaningful movies more than do younger viewers (Bartsch, 2012; Hofer, Allemand, \& Martin, 2014), and that mortality effects are stronger for older people who are faced with their mortality on a more regular basis (Taubman Ben-Ari \& Findler, 2005). Investigating the interplay between mortality salience and meaningfulness in different age groups would therefore be worthwhile. As the current study used a typical student sample, comparing the socio-demographic variables of gender and age would also increase the generalizability of the results.

A final limitation and opportunity for future research lies in the nature of the dual processes described within TMT, which differentiates between proximal and distal anxiety buffers (Pyszczynski et al., 1999). Proximal effects occur when individuals are consciously aware of death-related anxiety. When this is the case, the main goal is to ensure cognitive functioning and to suppress paralyzing thoughts (Arndt, Greenberg, Solomon, Pyszczynski, \& Simon, 1997). However, when a distractor task is provided, individuals cease to be consciously aware of their death-related thoughts, although the thoughts remain highly accessible (Hayes, Schimel, Arndt, \& 
Faucher, 2010). In the field of TMT, studies that showed participants a movie after mortality priming can be interpreted as naturally incorporating a distractor or delay that enabled participants to engage their distal defenses (Frischlich, Rieger, Dratsch, et al., 2014; Kneer, Hemme, \& Bente, 2011). We argue that our movie contained elements that functioned as a distal anxiety buffer by providing viewers with a meaningful experience (i.e., appreciation) and a close relationship with the protagonist, which we assessed using items that measured how much the viewers liked and cared for the protagonist. The movie stimulus in the present study was long enough (approximately 30 minutes) for thoughts of death to remain outside conscious awareness and hence to put distal defense mechanisms into play. However, the lack of a distractor before the movie reception phase may have allowed the participants to activate their proximal defenses. In addition, we argued above that the survival of the protagonist could even be interpreted as some form of proximal defense (i.e., by pushing death into the distant future). The present study design did not allow us to test directly for the differences between proximal and distal processes, as we did not include a condition with a delay between the mortality salience induction and watching the film. Consequently, we cannot determine whether the meaningful movie worked as a proximal or distal defense mechanism, and we leave this distinction to be explored in future studies.

\section{Conclusion}

The current study provides evidence for the notion that meaningful films — or at least certain aspects of them - can serve an anxiety-buffering function when a person is confronted with thoughts about his or her own death. We therefore contribute to the literature by expanding on the idea that meaningful movies comprise elements that serve as an internal anxiety buffer, which helps people to cope with death-related thoughts and thereby makes other film-external 
anxiety buffers obsolete. We also introduce the idea that depicting the survival of the protagonist can serve as an anxiety buffer. 


\section{References}

\section{AUTHORS}

\section{AUTHORS}

Adler, A. (1980). What life should mean to you ((Originall.). London: George Allen \& Unwin.

Arndt, J., Greenberg, J., Schimel, J., Pyszczynski, T., \& Solomon, S. (2002). To belong or not to belong, that is the question: Terror management and identification with gender and ethnicity. Journal of Personality and Social Psychology, 83(1), 26-43. doi:10.1037//00223514.83.1.26

Arndt, J., Greenberg, J., Solomon, S., Pyszczynski, T., \& Simon, L. (1997). Suppression, accessibility of death-related thoughts, and cultural worldview defense: exploring the psychodynamics of terror management. Journal of Personality and Social Psychology, 73(1), 5-18. doi:10.1037/0022-3514.73.1.5

Arndt, J., \& Vess, M. (2008). Tales from existential oceans: Terror management theory and how the awareness of our mortality affects us all. Social and Personality Psychology Compass, 2, 909-928. doi:10.1111/j.1751-9004.2008.00079.x

Bartsch, A. (2012). As time goes by: What changes and what remains the same in entertainment experience over the life span? Journal of Communication, 62, 588-608. doi:10.1111/j.14602466.2012.01657.x

Baumeister, R. F., \& Vohs, K. D. (2002). The pursuit of meaningfulness in life. In C. R. Snyder \& S. J. Lopez (Eds.), Handbook of positive psychology (pp. 608-618). Oxford: Oxford University Press.

Bosshart, L., \& Macconi, I. (1998). Media entertainment. Communication Research Trends, $18(3), 3-8$.

Burke, B. L., Kosloff, S., \& Landau, M. J. (2013). Death goes to the polls: A meta-analysis of mortality salience effects on political attitudes. Political Psychology, 34(2), 183-200. doi:10.1111/pops. 12005

Dechesne, M., Greenberg, J., Arndt, J., \& Schimel, J. (2000). Terror management and the vicissitudes of sports fan affiliation : the effects of mortality salience on optimism and fan identification. European Journal of Social Psychology, 835, 813-836. doi:10.1002/10990992(200011/12)30:6

DeWall, N. C., \& Baumeister, R. F. (2007). From terror to joy: Automatic tuning to positive affective information following mortality salience. Psychological Science, 18(11), 984-90. doi:10.1111/j.1467-9280.2007.02013.x 
Frischlich, L., Rieger, D., Dratsch, T., \& Bente, G. (2014). Meet Joe Black? The effects of mortality salience and similarity on the desire to date in-group versus out-group members online. Journal of Social and Personal Relationships, Advance On, 1-20. doi:10.1177/0265407514536305

Frischlich, L., Rieger, D., Dratsch, T., \& Bente, G. (2015). Meet Joe Black? The effects of mortality salience and similarity on the desire to date in-group versus out-group members online. Journal of Social and Personal Relationships, 32(4), 509-528. doi:10.1177/0265407514536305

Frischlich, L., Rieger, D., \& Rutkowski, O. (2014). I'd rather die than be with you. The effects of mortality salience and negative social identity on identification with a virtual group. Lecture Notes in Computer Science, 8531, 411-420. doi:10.1007/978-3-319-07632-4_42

Goldenberg, J. L., Arndt, J., Hart, J., \& Brown, M. (2005). Dying to be thin: the effects of mortality salience and body mass index on restricted eating among women. Personality and Social Psychology Bulletin, 31(10), 1400-12. doi:10.1177/0146167205277207

Goldenberg, J. L., Pyszczynski, T., Johnson, K. D., Greenberg, J., \& Solomon, S. (1999). The appeal of tragedy: A terror management perspective. Media Psychology, 1, 313-329. doi:10.1207/s1532785xmep0104_2

Greenberg, J., Pyszczynski, T., \& Solomon, S. (1986). The causes and consequences of a need for self-esteem: A Terror Management Theory. In R. F. Baumeister (Ed.), Public self and private self (pp. 189-212). New York, USA: Springer-Verlag.

Greenberg, J., Pyszczynski, T., Solomon, S., Rosenblatt, A., Veeder, M., \& Kirkland, S. (1990). Evidence for terror management theory II : The effects of mortality salience on reactions to those who threaten or bolster the cultural worldview. Journal of Personality and Social Psychology, 58(2), 308-318. doi:10.1037/0022-3514.58.2.308

Greenberg, J., Pyszczynski, T., Solomon, S., Simon, L., \& Breus, M. (1994). Role of consciousness and accessibility of death-related thoughts in mortality salience effects. Journal of Personality and Social Psychology, 67(4), 627-37. doi:10.1037/00223514.67.4.627

Greenberg, J., Simon, L., Harmon-Jones, E., Solomon, S., Pyszczynski, T., \& Lyon, D. (1995). Testing alternative explanations for mortality salience effects - Terror management, value accessibility, or worrisome thoughts? European Journal of Social Psychology, 25(4), 417433. doi:10.1002/ejsp.2420250406

Greenberg, J., Solomon, S., \& Pyszczynski, T. (1997). Terror management theory of self-esteem and cultural worldviews: Empirical assessments and conceptual refinements. Advances in Experimental Social Psychology, 29, 61-139. doi:10.1016/S0065-2601(08)60016-7 
Harmon-Jones, E., Simon, L., Greenberg, J., Pyszczynski, T., Solomon, S., \& McGregor, H. (1997). Terror management theory and self-esteem: Evidence that increased self-esteem reduces mortality salience effects. Journal of Personality and Social Psychology, 72(1), 2436. doi:10.1037//0022-3514.72.1.24

Hartmann, T., \& Goldhoorn, C. (2011). Horton and Wohl revisited: Exploring viewers' experience of parasocial interaction. Journal of Communication, 61, 1104-1121.

Hayes, J., Schimel, J., Arndt, J., \& Faucher, E. H. (2010). A theoretical and empirical review of the death-thought accessibility concept in terror management research. Psychological Bulletin, 136(5), 699-739. doi:10.1037/a0020524

Heine, S., Proulx, T., \& Vohs, K. (2006). The meaning maintenance model: On the coherence of social motivations. Personality and Social Psychology Review, 10(2), 88-110. doi:10.1207/s15327957pspr1002

Hofer, M. (2013). Appreciation and enjoyment of meaningful entertainment: The role of mortality salience and search for meaning in life. Journal of Media Psychology: Theories, Methods, and Applications, 25(3), 109-117. doi:10.1027/1864-1105/a000089

Hofer, M., Allemand, M., \& Martin, M. (2014). Age differences in nonhedonic entertainment experiences. Journal of Communication, 64(1), 61-81. doi:10.1111/jcom.12074

Hoffner, C., \& Buchanan, M. (2005). Young adults' wishful identification with television characters: The role of perceived similarity and character attributes. Media Psychology, 7(4), 325-351. doi:10.1207/S1532785XMEP0704_2

Johnson, B. K., Ewoldsen, D. R., \& Slater, M. D. (2015). Self-control depletion and narrative: Testing a prediction of the TEBOTS Model. Media Psychology, 18(2), 196-220. doi:10.1080/15213269.2014.978872

Johnson, B. K., Slater, M. D., Silver, N. A., \& Ewoldsen, D. R. (2016). Entertainment and expanding boundaries of the self: Relief from the constraints of the everyday, 1-23. doi:10.1111/jcom.12228

Jonas, F. E., Mcgregor, I., Klack1, J., Agroskin, D., Fritsche, I., Holbrook, C., ... Proulx, T. (2014). Threat and defense : From anxiety to approach. Advances in Experimental Social Psychology, 49, 219-286. doi:10.1016/B978-0-12-800052-6.00004-4

Klimmt, C. (2011). Media psychology and complex modes of entertainment experiences. Journal of Media Psychology: Theories, Methods, and Applications, 23(1), 34-38. doi:10.1027/1864-1105/a000030

Kneer, J., Hemme, I., \& Bente, G. (2011). Vicarious belongingness. Effects of socioemotional commercials under mortality salience. Journal of Media Psychology: Theories, Methods, and Applications, 23(3), 133-140. doi:10.1027/1864-1105/a000045 
Kneer, J., \& Rieger, D. (2016). The memory remains: How heavy metal fans buffer against the fear of death. Psychology of Popular Media Culture, 5(3), 258-272. doi:10.1037/ppm0000072

Kosloff, S., Greenberg, J., Sullivan, D., \& Weise, D. (2010). Of trophies and pillars: Exploring the terror management functions of short-term and long-term relationship partners. Personality and Social Psychology Bulletin, 36(8), 1037-51. doi:10.1177/0146167210374602

Mikulincer, M., \& Florian, V. (2000). Exploring individual differences in reactions to mortality salience: does attachment style regulate terror management mechanisms? Journal of Personality and Social Psychology, 79(2), 260-73. doi:10.1037/0022-3514.79.2.260

Mikulincer, M., Florian, V., Birnbaum, G., \& Malishkevich, S. (2002). The death-anxiety buffering function of close relationships: Exploring the effects of separation reminders on death-hought accessibility. Personality and Social Psychology Bulletin, 28(3), 287-299. doi:10.1177/0146167202286001

Mikulincer, M., Florian, V., \& Hirschberger, G. (2003). The existential function of close relationships: Introducing death into the science of love. Personality and Social Psychology Review, 20, 20-40. doi:10.1207/S15327957PSPR0701_2

Mussweiler, T., \& Bodenhausen, G. V. (2002). I know you are, but what am I? Self-evaluative consequences of judging in-group and out-group members. Journal of Personality and Social Psychology, 82(1), 19-32. doi:10.1037//0022-3514.82.1.19

Norenzayan, A., \& Hansen, I. G. (2006). Belief in supernatural agents in the face of death. Personality and Social Psychology Bulletin, 32(2), 174-187. doi:10.1177/0146167205280251

Oliver, M. B. (2008). Tender Affective States as Predictors of Entertainment Preference. Journal of Communication, 58(1), 40-61. doi:10.1111/j.1460-2466.2007.00373.x

Oliver, M. B., \& Bartsch, A. (2010). Appreciation as audience response: Exploring entertainment gratifications beyond hedonism. Human Communication Research, 36(1), 53-81. doi:10.1111/j.1468-2958.2009.01368.x

Oliver, M. B., \& Bartsch, A. (2011). Appreciation of entertainment. Journal of Media Psychology: Theories, Methods, and Applications, 23(1), 29-33. doi:10.1027/18641105/a000029

Oliver, M. B., \& Hartmann, T. (2010). Exploring the role of meaningful experiences in users' appreciation of "good movies." Projections: The Journal of Movies and Mind, 4(2), 128150. doi:10.3167/proj.2010.040208

Oliver, M. B., Hartmann, T., \& Woolley, J. K. (2012). Elevation in response to entertainment 
portrayals of moral virtue. Human Communication Research, 38, 360-378.

doi:10.1111/j.1468-2958.2012.01427.x

Oliver, M. B., \& Raney, A. A. A. (2011). Entertainment as pleasurable and meaningful: Identifying hedonic and eudaimonic motivations for entertainment consumption. Journal of Communication, 61(5), 984-1004. doi:10.1111/j.1460-2466.2011.01585.x

Pyszczynski, T., Greenberg, J., \& Solomon, S. (1999). A dual-process model of defense against conscious and unconscious death-related thoughts: An extension of Terror Management theory. Psychological Review, 106(4), 835-845. doi:10.1037//0033-295X.106.4.835

Pyszczynski, T., Greenberg, J., Solomon, S., Arndt, J., \& Schimel, J. (2004). Why do people need self-esteem? A theoretical and empirical review. Psychological Bulletin, 130(3), 435-68. doi:10.1037/0033-2909.130.3.435

Raney, A. A. (2003). Disposition-based theories of enjoyment. In J. Bryant, D.-. R. RoskosEwoldsen, \& J. Cantor (Eds.), Communication and emotion: Essays in honor of Dolf Zillmann (pp. 61-84). Mahwah, N.J.: Lawrence Erlbaum Associates.

Rieger, D., Reinecke, L., Frischlich, L., \& Bente, G. (2014). Media entertainment and well-beinglinking hedonic and eudaimonic entertainment experience to media-induced recovery and vitality. Journal of Communication, 64(3), 456-478. doi:10.1111/jcom.12097

Routledge, C., Arndt, J., \& Goldenberg, J. L. (2004). A time to tan: Proximal and distal effects of mortality salience on sun exposure intentions. Personality and Social Psychology Bulletin, 30(10), 1347-58. doi:10.1177/0146167204264056

Schiappa, E., Gregg, P. B., \& Hewes, D. E. (2004). Can a television series change attitudes about death? A study of college students and Six Feet Under. Death Studies, 28(5), 459-74. doi:10.1080/07481180490437581

Schmeichel, B. J., Gailliot, M., Filardo, E.-A., McGregor, I., Gitter, S., \& Baumeister, R. F. (2009). Terror management theory and self-esteem revisited: The roles of implicit and explicit self-esteem in mortality salience effects. Journal of Personality and Social Psychology, 96(5), 1077-87. doi:10.1037/a0015091

Sestir, M., \& Green, M. C. (2010). You are who you watch: Identification and transportation effects on temporary self-concept. Social Influence, 5(4), 272-288. doi:10.1080/15534510.2010.490672

Slater, M. D., Johnson, B. K., Cohen, J., Comello, M. L. G., \& Ewoldsen, D. R. (2014). Temporarily expanding the boundaries of the self: Motivations for entering the story world and implications for narrative effects, 64, 439-455. doi:10.1111/jcom.12100

Sullivan, D., \& Greenberg, J. (2013). Death in classic and contemporary film. Fade to black. New York, NY. 
Swann, W. B., \& Brooks, M. (2012). Why threats trigger compensatory reactions: the Need for coherence and quest for self-verification. Social Cognition, 30(6), 758-777.

doi:10.1521/soco.2012.30.6.758

Taubman Ben-Ari, O., \& Findler, L. (2005). Proximal and distal effects of mortality salience on willingness to engage in health promoting behavior along the life span. Psychology \& Health, 20(3), 303-318. doi:10.1080/08870440512331317661

Taylor, L. D. (2012). Death and television: Terror management theory and themes of law and justice on television. Death Studies, 36, 340-359. doi:10.1080/07481187.2011.553343

Taylor, L. D. (2013). Dying to watch. Thoughts of death and preferences for sexual media conte.t. Journal of Media Psychology: Theories, Methods, and Applications, 25(2), 55-64. doi:10.1027/1864-1105/a000079

Tsay, M., Krakowiak, M. K., \& Oliver, M. B. (2012). Exploring the impact of cognitively challenging content on mortality salience. In Paper presented at the 62nd Conference of the International Communication Association (ICA), 24.-28.05.2012. Phoenix, Arizona, USA, Arizona, USA.

Vess, M., Routledge, C., Landau, M. J., \& Arndt, J. (2009). The dynamics of death and meaning: The effects of death-relevant cognitions and personal need for structure on perceptions of meaning in life doi:10.1037/a0016417. Journal of Personality and Social Psychology, 97, $728-744$.

Vorderer, P. (2011). What's next? Remarks on the current vitalization of entertainment theory. Journal of Media Psychology, 23, 60-63. doi:10.1027/1864-1105/a000034

Vorderer, P., Klimmt, C., \& Ritterfeld, U. (2004). Enjoyment: At the heart of media entertainment. Communication Theory, 14(4), 388-408. doi:10.1111/j.14682885.2004.tb00321.x

Wirth, W., Hofer, M., \& Schramm, H. (2012). Beyond pleasure: Exploring the eudaimonic entertainment experience. Human Communication Research, 38(4), 406-428. doi:10.1111/j.1468-2958.2012.01434.x

Wisman, A., \& Heflick, N. A. (2015). Hopelessly mortal: The role of mortality salience, immortality and trait self-esteem in personal hope. Cognition and Emotion, (June), 1-22. doi:10.1080/02699931.2015.1031643

Zamora, J. H. (2006). Life is good after brush with death. San Francisco Chronicle, p. A1. San Francisco, California. 
Tables and Figures

Table 1. Means, standard deviations, and simple pairwise comparisons for all three dependent variables, split by condition.

\begin{tabular}{|c|c|c|c|c|c|}
\hline \multirow{3}{*}{$\begin{array}{l}\text { Dependent } \\
\text { Variable }\end{array}$} & \multirow[t]{3}{*}{ Priming } & \multicolumn{4}{|c|}{ Protagonist's Death/Survival } \\
\hline & & \multicolumn{2}{|c|}{ Survival } & \multicolumn{2}{|c|}{ Death } \\
\hline & & $M$ & $S D(S E)$ & $M$ & $S D(S E)$ \\
\hline \multicolumn{6}{|c|}{ Appreciation } \\
\hline & $\begin{array}{l}\text { Mortality } \\
\text { Salience }\end{array}$ & $5.48 \mathrm{a}$ & 0.89 & $4.77_{\mathrm{b}}$ & 1.27 \\
\hline & Control & $4.41_{b}$ & 1.45 & $4.30_{b}$ & 1.79 \\
\hline \multicolumn{6}{|l|}{ Liking } \\
\hline & $\begin{array}{l}\text { Mortality } \\
\text { Salience }\end{array}$ & $4.41_{\mathrm{a}}$ & 0.46 & $3.97 \mathrm{a}$ & 0.67 \\
\hline & Control & $3.87_{b}$ & 0.99 & $3.80_{\mathrm{b}}$ & 0.95 \\
\hline \multicolumn{6}{|l|}{ Self-Esteem } \\
\hline & $\begin{array}{l}\text { Mortality } \\
\text { Salience }\end{array}$ & $240.11_{\mathrm{a}}$ & -74.57 & $10.80_{a}$ & -74.57 \\
\hline & Control & $-49.03_{a}$ & -72.28 & $39.69_{b}$ & -71.84 \\
\hline
\end{tabular}

Note. Different subscripts per dependent variable, line, and row indicate significant simple pairwise comparisons, $p<.05$.

Values for the dependent variable, self-esteem, are estimated values based on a covariate of baseline self-esteem $=-118.44$. 


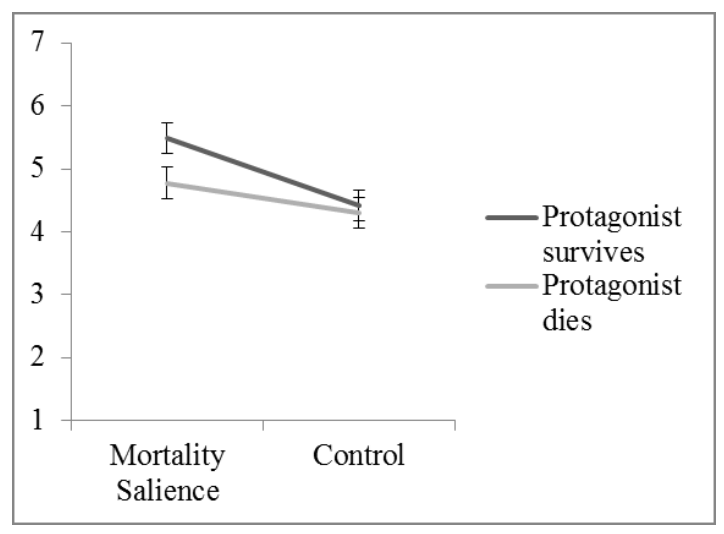

Figure 1. Effects of mortality salience and

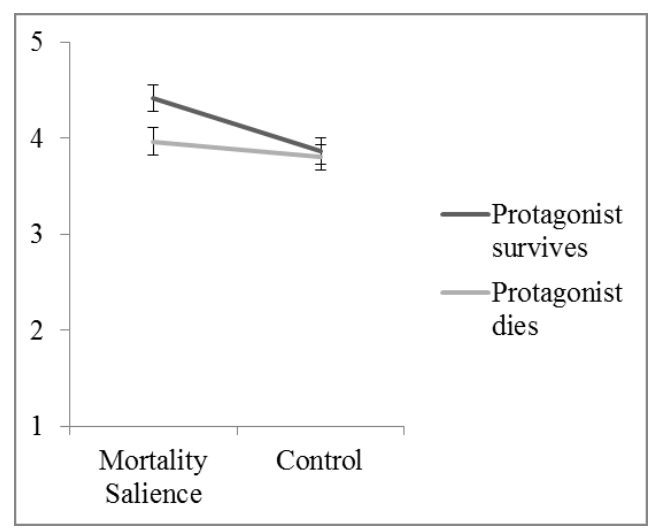

Figure 2. Effects of mortality salience and protagonist's death or survival on appreciation. protagonist's death or survival on liking.

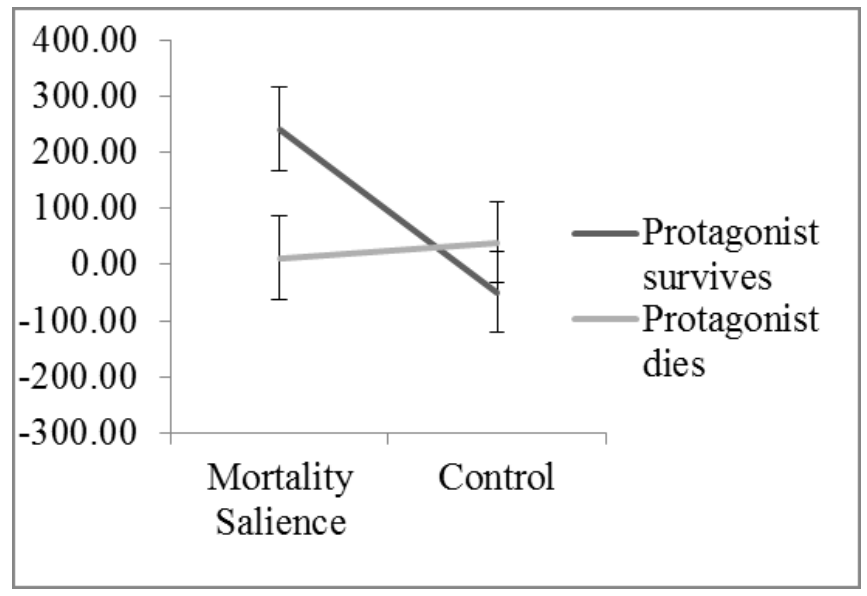

Figure 3. Effects of mortality salience and protagonist's death or survival on self-esteem (difference between response times for self-esteem-relevant adjectives $\left(\mathrm{Adj}_{\text {pos }}-\mathrm{Adj}_{\mathrm{neg}}\right)$ ). Baseline difference in response times served as a covariate in the analysis $=-118.44$. 